\title{
ANALYSIS OF ECONOMIC-FINANCIAL EXPERIENCE OF THE WORLD COUNTRIES IN THE SYSTEM OF PENSION INSURANCE
}

\author{
Natalia Koval' ${ }^{\text {, Natalia Priamuhina², Inna Zhmurko³ }}$
}

\begin{abstract}
The purpose of this article is to analyze the experience of pension insurance systems in Europe, Asia, North and South America, Australia. The defining feature is that the existing pension insurance system in Ukraine does not perform its main task properly, since the rate of pension, for the most part, does not make it possible to maintain a decent standard of living for current pensioners. After analyzing the implementation of the pension reform in Ukraine, it should be emphasized that during the twelve-year period after the pension reform in the country there remain a number of unresolved issues regarding the pension provision of citizens, namely: aging of the population, which is one of the main factors that prompt the government to a new stage of reforming the pension system; the presence of arrears on contributions to compulsory state pension insurance; lack of proper differentiation of pension payments; shadow wages; lack of sound financial instruments for investing pension assets; unsatisfactory level of legal and financial awareness of the population in matters of pension provision; lack of interest of employers in financing non-state pension programs for employees, lack of confidence in the pension system of non-state pension funds. Methods. In most countries of the world, the problems of the pension system, same to what we have in our country, arose. But due to pension reform, they achieved successful results. Each country chose its own way of building a pension system based on its own demographic and socioeconomic features. However, despite this, the main task of any pension system is to secure from poverty and provide a pension that could guarantee a decent standard of living for a pensioner. Results. Ukraine is trying to build the pension insurance system, drawing on the best practice of the countries studied. Practical implications. It is found that the most effective and successful model of the pension system is considered to be Chilean, since the country has been using cumulative and voluntary pension systems for a long time, which are priority and allow to resolve the pension of their citizens financially, prudent and efficient investing of pension funds with lower rates of public investment income. The same model was taken as the basis in Peru, Argentina, Colombia and Kazakhstan. Value/originality. Analyzing the pension reforms implemented in Eastern Europe, it should be noted that part of the changes was due to the need to protect pensioners from poverty in the context of a sharp decrease in the rate of pensions because of the reduction of total pension contributions and the inability of the state to finance previous pension obligations. The real way to reduce the financial burden on employers and the state in the context of a solidarity pension system was to develop levels II and III of the pension system. It is noteworthy to study the foreign experience of the Eastern European country, such as Poland, which was one of the first to introduce a compulsory funded pension system.
\end{abstract}

Key words: economic-financial experience, Ukraine, pension insurance, Eurasian countries, North and South America, Australia, personal pension insurance, pension insurance systems, foreign experience.

JEL Classification: G22, G23, 057

\footnotetext{
Corresponding author:

${ }^{1}$ Vinnytsia National Agrarian University, Ukraine.

E-mail: natkov@i.ua

ORCID: https://orcid.org/0000-0002-2877-4302

${ }^{2}$ Vinnytsia National Agrarian University, Ukraine.

E-mail: 877muha@gmail.com

ORCID: https://orcid.org/0000-0003-0788-7399

${ }^{3} \mathrm{Khmelnytskyi}$ Educational and Scientific Institute of

Ternopil National Economic University, Ukraine.

E-mail: zhmyrko_iv@ukr.net

ORCID: https://orcid.org/0000-0002-5678-6343
} 


\section{Introduction}

The existing system of pension insurance in Ukraine does not fulfill its main task properly, since the rate of pension, for the most part, does not make it possible to maintain a decent standard of living for current pensioners. After analyzing the implementation of the pension reform in Ukraine, it should be emphasized that during the twelve-year period after the pension reform in the country there remain a number of unresolved issues regarding the pension provision of citizens, namely: aging of the population, which is one of the main factors that prompt the government to a new stage of reforming the pension system; the presence of arrears on contributions to compulsory state pension insurance; lack of proper differentiation of pension payments; shadow wages; lack of sound financial instruments for investing pension assets; unsatisfactory level of legal and financial awareness of the population in matters of pension provision; lack of interest of employers in financing non-state pension programs for employees, lack of confidence in the pension system of non-state pension funds.

The statement mentioned above undeniably confirms the necessity of reforming the pension system of Ukraine. Due to the changes in the pension system in the country, the living standards of pensioners will increase, financial stability of the pension system will be ensured, pension insurance arrears will be impossible, a more effective system of administrative management of pensions will be created and the level of social protection of the population will increase.

In order to reform the pension system in Ukraine successfully and efficiently, it is expedient to consider the foreign experience of pension insurance and analyze the different approaches of the countries to the role of the state in the organization and functioning of pension programs. The analysis of pension systems in different countries performed convinces that in the world practice there are three ways of providing pension benefits to the elderly: through taxes and a solidarity system based on exchanges between generations when current employees pay for pensioners and by saving money (financing scheme), that is employees save some of their income by accumulating them on personal, individual accounts for use after retirement.

\section{Economic crisis effects on consumer behaviour}

Let us take a closer look at typical approaches to reform pension systems around the world and the corresponding models of pensions that have a number of peculiarities: the Eurasian countries (Germany, Poland, France, Russia, Latvia, Estonia, Bulgaria, the United Kingdom, Kazakhstan, Sweden), North and South America (Canada, the USA, Chile) and Australia.
The world experience in reforming pension systems shows that the main trend is the transition to a cumulative pension system, the positive side of which is the possibility of increasing investment in the economy and obtaining investment income for persons of retirement age, which makes it possible to make the domestic pension system financially balanced and sustainable. Since in order to raise the level of pension benefits for citizens, non-state pension funds in many countries of the world are one of the main instruments.

The first countries in the world that introduced compulsory state pension insurance based on the principles of redistribution and solidarity of generations and usage of the multi-level pension model, were the most economically developed countries of Western Europe, among which we mention Germany, France, Great Britain and Sweden.

The first full system in the world was introduced by Otto von Bismarck in Germany in 1889, a system of compulsory retirement provision, which was characterized the principle of solidarity of generations and the level of social security of the population. The pension system of this country consisted of three levels: compulsory state pension insurance, industrial pension insurance and private pension insurance.

As for private pension insurance, it involves person taking care about his/her old age in a private way. For this purpose, pension schemes of this type of insurance which are voluntary, have been adopted, the rate of pension assets of their participants is determined which depends on the amount of insurance premiums paid and the received investment income.

The pension provision of the employed in agriculture is performed regardless of the pensions of workers and employees. Unlike pensions for state social insurance, the help of peasants in old age did not provide for their full allowance; funds for the help of old age peasants consisted of equal deductions of agricultural entrepreneurs in general insurance, although in the future it is planned to transit them to the national system of pension insurance.

The main feature of the German pension system, which differs from the other EU countries, lies in the fact that it provides more than $85 \%$ of all pensions in this country. It should be noted that pension reform in Germany was started back in 1992, which adapted the pension system to future demographic and economic conditions. Every year the functioning of cumulative pension programs grew in the state, which allowed to form a powerful financial source for replenishing citizens' incomes when they reached their retirement age (Aleskerova, 2018).

It should be emphasized that Germany's pension system is considered one of the most effective in Europe, it affects the development and formation of pension systems in many countries of the world. 
Another noteworthy structure is the French pension system, which is based on the model of "Otto von Bismarck Social Insurance Model", where compulsory state pension insurance, which is based on the principles of redistribution and solidarity of generations, plays a leading role. The pension system of this country is considered one of the most fair in the world and is quite complex and multicomponent because there are over 100 basic and 300 additional types of pensions in France.

In general, the pension system consists of 5 components: the main is for hired workers; additional; special is for certain categories of employed; basic is for officially unemployed workers; optional modes.

In France, the wage bill was calculated for the entire working period and not for the years with the highest earnings chosen. In the basic scheme of the pension system, early retirement is possible as well as a system of supplements for spouses with at least 3 children and one spouse who provides his/her payroll to the other, who does not have pension.

When analyzing the functioning pension system of France one should draw attention to the fact that the country prefers a solidarity system based on the solidarity of generations and operates at the expense of workers and employers who provide payment of pensions from the basic solidarity regime and with regard to cumulative pension funds, then they are voluntary and do not play a significant role in the country (Aleskerova, 2018).

As in Germany, in France there is a separate pension scheme for agricultural producers. The law of the country dated January 17, 1948 consolidated the creation of individual pension schemes for farmers, craftsmen and owners of small enterprises.

Therefore having analyzed the pension models of Germany and France, built on the "The Bismarck model" of social insurance, it is worth considering their main characteristics. The positive feature of these pension systems is that they play a major role in compulsory state pension insurance which is based on the principles of redistribution and solidarity of generations which provides approximately $70-80 \%$ of the basic pension. The existing high replacement rate of salary wages varies between $60-80 \%$ which, on the one hand, is a positive aspect of this model since it provides a high standard of living for pensioners, and, on the other hand, such a high replacement rate leads to a deficit in pension systems in the future. Regarding the retirement provision of agricultural workers, pension schemes are being created in these countries which are funded by contributions from the employees themselves and from public funds (Polyova, 2017).

The next peculiarity of pension provision to be considered is the model performed in the UK, as it is the only country in Western Europe that was hardly affected by the crisis of pension systems in Europe; its pension system has always been solvent and reasonably considered one of the most advanced in the world.

The UK pension model is based on three levels, which include basic state pensions, additional state superannuation pension and non-state pension savings. The basic state pensions are at the first level, the rate of which depends on the length of service and the amount of wages and guaranteed by the state to all Britons after reaching their retirement age of 60 years for women and 65 years for men, they intend to increase in the future for another 5 years, that is up to 70 years. The basic part of the state pension is $12 \%$ of the average wage paid to all citizens. The second level is additional state superannuation pension, the amount of which depends on the amount of pension savings accumulated on individual accounts of a person in the bank and on average amounts to $50 \%$ of the employee's salary before retirement. In particular, funds and investment income accumulated in the pension fund are not subject to tax. With regard to the third level, the non-state pension system, there are many ways for accumulating private pensions in the United Kingdom. Professional pension systems are the most widespread. Significant role is played by insurance companies that provide a range of services for additional pension provision of the population. Non-state pension funds are most popular among the UK citizens, as they are one of the main tools for raising the level of retirement provision of the population. If comparing the rates of development of the NPFs, the UK and Ukraine, it should be emphasized that the population of the United Kingdom is $100 \%$ covered by basic state pensions, $50 \%$ by the system of professional pensions and by $25 \%$ by the scheme of personal pensions with regard to Ukraine's state pensions is also covered $100 \%$ of the population and only $7 \%$ by the scheme of personal pensions.

Instead, in the United Kingdom, as in many other European countries, pension reform is one of the most important political steps in social policy. After all the government of the state has always encouraged citizens to accumulate funds for old age rather than hoping for a state pre-funded pension system.

The negative aspects of the British system should include the inadequate level of pension provision for the entire population as well as the dependence of future retirement benefits on various changes in the economy of both the country and the world, in particular changes in investment income, inflation, economic growth, etc.

\section{Differences in consumer spending behaviour among age groups}

The most successful and universal, from a social point of view, is the pension system in Sweden with compulsory defined payments, which consists of a labor pension related to the earnings of the additional pension and a national, basic state pension system operating through 
a distribution mechanism at the expense of insurance contributions amounting to $18.5 \%$ of earnings, $16 \%$ of which come to the public service (Aleskerova, 2018).

The solidarity level of the Swedish pension system involves a distributive character, which is shaped by the contributions of currently working citizens, which provide retirement benefits to current pensioners. It contributes to the formation of a wage-dependent pension as well as a guaranteed social pension, which is paid if the pension level does not reach $20 \%$ of the average wage in the country. It should be emphasized that the level of future pensions is indexed annually according to the dynamics of the average wage and the general state of the economy of Sweden.

The second level of the pension model is based on the principles of cumulative retirement insurance which involves the creation of cumulative retirement accounts. Pension insurance premiums are collected by the state and managed by a future pensioner in Sweden, having the opportunity to invest them in one or more investment funds. These financial institutions offer investment products with different profitability which gives the citizen opportunity to independently choose an investment strategy. If the second level participants do not choose financial instruments for their retirement assets independently, then the assets are on state fund accounts. However, approximately $58 \%$ of Sweden's population prefers to independently choose financial instruments for their retirement assets (Nicoholas, 2002).

It should be noted that the structure of the Swedish pension system is very similar to that implemented in Ukraine, but there are certain differences. In Sweden the pension rate is $18 \%$ lower than in Ukraine where the employer deduct to the Pension Fund approximately $36.6 \%$ of the wage bill, while in Sweden it is only $18.5 \%$. Of this rate, $16 \%$ go to the formation of a distribution pension and the other $2.5 \%$ goes to the cumulation account (Aleskerova, 2018).

Summarizing the results of the survey on Sweden's modern pension system, we would point out that it can be a useful example for most of the countries that are currently reforming pension systems. In virtue of the pension reform, Sweden managed to minimize the negative effects of reform and maximally change its pension system in line with those processes taking place in the world, providing financial stability in the future.

The analysis of pension systems in economically developed countries has shown that they all have welldeveloped retirement benefits systems for the elderly. From the social point of view, the pension systems of Sweden and the Great Britain are the most acceptable. It is these pension systems, their financial support mechanisms and the social and legal protection of all participants can serve as the example for Ukraine in building a new pension system.
It should be noted that the countries under research are more reliant on state pension insurance with the exception of the Great Britain, so it is expedient to analyze the pension systems of those countries based mostly on private pension systems: these are the countries of Latin America.

It should be noted that such countries, in particular, the USA, Canada, Chile, have a developed solidarity pension system with large public expenditures on pensions and are economically developed, where a cumulative pension system is implemented, which in the early years of the reform was the main part of pension assets invested in state securities and deposits of banks and only with the development of the corporate securities market diversified investment portfolio of pension funds.

Thus, in the United States, there is a two-level pension provision model which includes the first level, a solidarity system complemented by other pension programs that enable citizens to save their funds for retirement benefits and the third level, which is a system of voluntary private pension funds that enables citizens who have a desire to receive an even bigger pension and pay large contributions in a long period of work to maintain the desired level of retirement. The second level of compulsory pension funds in the USA pension model is absent. Every American has the opportunity to provide three pensions: state, non-state at work and nonstate individual through the opening the personal pension accounts. The aggregate tax rate on the wage fund with the functioning of the American model of the pension system is $15.3 \%$, which is paid in equal installments by the employer and employee with the pension tax having an aggregate rate of $10.7 \%$ and paid in equal shares by the employer and employees.

The United States was one of the first to solve the problem of "pension" deficits by raising the rate of pension insurance. The USA pension model operates in Portugal as well as in some countries of America (Rogach, 2019).

The model of the USA pension system is based mainly on personal pension insurance of the population. The pension system is based on a distribution pension system and a system of voluntary private pension funds, types of pension programs of which play both a social and an investment role.

The positive side of the USA social security system, the experience of which can be used in reforming the pension system in Ukraine, is to develop strategic aspects based on forecasts of changes in demographic and economic conditions.

In general the Anglo-American model of pension insurance has several advantages over the Bismarck Social Security model. First, compulsory state pension insurance does not play such an important role as in continental Europe, as it provides social assistance to the most vulnerable groups of the population and 
people with high incomes can worry about their pensions on their own. This will have a positive effect on the financial sustainability of pension systems in these countries in the future since they are less dependent on demographic changes in the world. Secondly, private pension systems operate efficiently in these countries which not only increase the financial sustainability of the national pension system but also serve as a powerful source of investment in the country's economy.

Canada's pension system ranks fourth in the world after the United States, Japan and the United Kingdom in terms of retirement assets. It consists of three levels: state pension (old-age pension); Cumulative Labor Pension (Canada Pension Plan) and Individual Pension Schemes.

In Canada, contributions from employers and workers are set at such a rate that in 10 years the supplementary pension insurance was $25 \%$ and in some other countries, Germany, Spain, the Great Britain, the amount of deductions is calculated on the basis that in 20 years the supplementary pension was not less than $20 \%$ of the salary of the employee subject to insurance.

Only a quarter of the Canadian population has its own individual pension schemes which allow them to contribute up to $18 \%$ of the income for the previous year. It is possible to make funds until reaching 69 years. All retirement benefits received by a person after reaching the retirement age are subject to tax.

The experience of the provision of pensions in Eastern Europe, the pension systems of which consist of three levels, among which Poland, the Czech Republic, Russia, Bulgaria, Kazakhstan should be noted, is also helpful (Plakhtii, 2019).

Unlike the reform of the pension system in Ukraine, which began in 2004, the reform of pension systems in most countries of Eastern Europe began in the early 90s of the $20^{\text {th }}$ century.

When analyzing pension reforms carried out in Eastern European countries, it should be noted that part of the change was due to the need to protect pensioners from poverty in the context of a sharp reduction in pensions as a result of a reduction in the total pension contributions and the state's inability to finance previous pension obligations. The real reduction of the financial burden on employers and the state in the conditions of the solidarity pension system was the development of the II and III levels of the pension system.

Poland's pension system is considered the most responsible in the world, since no cases of arrears have been recorded.

Having examined the new pension system of Poland after the pension reform, its main achievements should be named: introduction of personalization of the registration of contributions to the joint-stock system; a clear creation of the legislative framework and administrative infrastructure for the management and regulation of the compulsory accrual system; definition of rules for protecting the rights and interests of participants in the cumulation system; the introduction of a voluntary cumulative system of pension accounts.

It should be noted that the reform of the pension system in Ukraine should be based on the experience of Poland where the cumulated individual pension system was introduced in the late 90 s of the last century. The main changes that allowed Poland to receive an additional investment resource for the country's economy are that part of the funds goes to the state social insurance system, which provides pensions to people who did not have time to participate in the cumulation system, and part is on accounts of open pension funds, run by private companies.

The pension system in Bulgaria today has three levels: state; additional compulsory pension insurance, that is a cumulation system with individual accounts in a professional or universal pension fund; voluntary pension insurance which is carried out through the operation of non-state pension funds. The retirement age for women is 60 years, 63 years for men, and, in the case of insurance periods, 34 and 37 years, respectively. Currently, the Bulgarian pension system is financially unstable and depends to a large extent on revenues to the state budget. In order to improve the situation in the country, in December 2010, the National Assembly of the Republic of Bulgaria adopted amendments to the basic legislation in the area of pensions of the Social Insurance Code.

Main reforms:

- provisional contributions: an increase in the amount of contributions to the pension fund by $1.8 \%$ and from 2017 it is planned to increase the amount of contributions for universal pension funds by $2 \%$;

- work experience: during 2012-2020, a gradual increase in the length of service for 4 months is planned for each year until 37 years of service for women and 40 years for men are reached. The introduced formula in Bulgaria is an important step towards improving the pension system but at this stage it needs further adjustments.

Features of building their national pension system is characterized by Kazakhstan. Its pension system has differences that distinguish it from the Russian, Baltic and the Ukrainian pension model.

It is also worth considering the pension systems of the countries of the former Soviet Union: Latvia, Estonia and Lithuania.

Latvia introduced a three-level pension system that united the personal interest of every person in ensuring his/her own old age and solidarity of generations. The main principle of the system is: the bigger the social contribution is paid today, the bigger the pension will be tomorrow. The country's pension system is stable, averaging the demographic and financial risks inherent in each of the levels.

The first level (solidarity of generations) already operates and it is based on the principle of providing 
social tax deducted from the working population. The social contribution is $35.09 \%$ of the salary, the employer pays $24.09 \%$ and the employee pays $11 \%$, $20 \%$ of which is the pension component. Calculations and insurance payments are covered by the State Social Insurance Agency. Payment is made from the special state social insurance budget which is separated from the state budget of Latvia. Notional system provides pensions for people who have worked for at least 10 years and have reached the retirement age: 62 years for men and women.

The pension system in Estonia consists of three parts: basic pension, which is the same for all and does not depend on earnings; share of work experience, the amount of which is calculated for the period of work before 1998 and the share of insurance: the amount calculated for the work experience after January 1, 1999; 95\% of Estonian pensioners receive pensions through bank accounts. The social tax is $33 \%$, of which $13 \%$ is deducted on medical and $20 \%$ is on pension insurance. Since January 1, 2002, a compulsory cumulative system has been introduced in the country, the members of which are persons born after 1983. The third level is voluntary and gives the citizen the opportunity to choose between pension insurance and pension funds which provides for tax benefits. In Estonia, the retirement age for women is 61 years and 63 years for men. The average pension is 306 euros and the people's pension is 128.45 euros. The right to appoint a national pension in the country has persons who have reached the age of 63 years, provided that they reside in its territory for at least 5 years.

The high level of information technology development in Estonia has made it possible for the pension system to be simplified and affordable for every Estonian. The transparency of the pension system contributed to a high level of trust on the part of its participants and the flexibility of the implemented system provided it with success and viability in the period of political and legislative changes in society.

\section{Survey methodology}

In most countries of the world there were the same problems with the pension system as in our state. However, due to pension reform, they have succeeded. Each country has chosen its way of building a pension system based on its own demographic and socioeconomic peculiarities of development. However despite this the main tasks of any pension system are protection from poverty and the provision of a pension that could guarantee a decent standard of living for a pensioner.

At the current stage of reform, one of the key tasks is the introduction of compulsory cumulative pension insurance. Scientists and practitioners discuss this issue, seek out the optimal mechanism for its implementation. Therefore, the study and application of the experience of other countries with a developed market economy, where compulsory cumulative pension programs are already functioning for a long period and proved to be effective, may be useful for our state.

The Ukrainian authorities have decided that a Russian-Polish model of the pension system will be implemented in our country. Today, almost no solidarity and cumulative strategy is used in its pure form since most states are adherents of a mixed strategy. Therefore, the Ukrainian leadership plans to use a solidaritycumulative model in which all three levels will operate. In many countries pension systems come in exactly three levels.

The Polish pension system is similar to the Ukrainian one but it is advisable to consider its disadvantages and advantages. The main achievements of the Polish pension system and useful experience for Ukraine are the following:

1) the Polish law reflects only one means of legal protection of the assets of participants, guaranteeing participants of private pension funds the safety of their funds. The draft law "On Non-State Pension Funds", prepared in Ukraine, does not provide this;

2) implementation of personalized registration of contributions and earnings of all employees in Poland is also necessary for Ukraine;

3 ) the participants themselves choose the NPF to invest their contributions and in Ukraine it is assumed that all assets will be located only in the Office of the State.

The German concept consisting of elements of distributive and cumulative methods has proven itself in practice. Therefore, taking advantage of the German experience, Ukraine should pay attention to the benefits of this country's pension system. The experience of Estonia, where since 2001 the compulsory second level has been introduced, is useful for Ukraine. The success of Estonia's pension reform depended on the cooperation of the public and private sectors. Joint actions made it possible to find quick and inexpensive solutions at a low risk level. The experience of Kazakhstan can be successfully used in the process of implementation of the system of NPP in our state on a voluntary or obligatory basis.

According to the study less than 10\% of the GDP is spent on pensions by countries such as Estonia, Latvia, Bulgaria, Russia and most of the financial expenditures on pensions are in the United States, Great Britain, Chile, Australia.

Taking into account the further negative demographic trends according to the projected calculations by most foreign experts, the aging of the population will continue in the near future, which is why the governments of most countries plan to continue raising the retirement age. 
The highest retirement age is expected to be set in the UK: up to 68 years for men and women, the lowest in Russia: 60 years for men and 55 years for women, it is not planned to change it in the future. Now in the above-mentioned countries, the average retirement age for men is 63.3 years and for women it is 61 years. In the near future, raising the retirement age is planned by Germany and Australia.

Non-state pension insurance is becoming widespread in the world which allows citizens to receive high pensions. Non-state pension provision begins to occupy an extremely important place in the system of social protection of the working population.

It should be noted that the introduction of NPP in Ukraine later than in most other countries gives a certain advantage to the domestic economy, namely, the opportunity to retrieve the innovations already made in this field in other countries and to use only those developments, which have shown a good result in practice (Nicoholas, 2002).

Summarizing the study on foreign experience in reforming the pension system allows to use a lot of valuable insights for Ukraine.

A comparative analysis of world experience in reforming pension systems provides an opportunity to draw certain conclusions regarding the assessment of their advantages and disadvantages in order to apply foreign experience in building a full-fledged retirement provision in our country. In modern conditions in most countries of the world individual pension schemes and their combination are used.

Some countries such as France, Germany, Italy prefer a solidarity-based system financed by contributions to social security, retirement benefits that depend on past earnings. Other countries - Great Britain, Switzerland, Denmark - have introduced a system of "fixed rate" which is financed by taxes, which provides the main income, regardless of paid contributions and wages. Most highly developed countries such as the United States, Great Britain operate through two compulsory pension systems that have successfully combined a common solidarity system and a cumulative one.

It should be noted that most of the developed European countries, including Germany, Poland, France, the Czech Republic, Sweden, Japan, Hungary, also the USA carried out the main important measures that, according to the needs of reforming pension systems included: gradual increase of the retirement age, reduction of the rate of certain types of pensions, increase of insurance premiums and duration of work experience.

\section{Findings}

The greatest interest for our country is the implementation of pension reform in the countries of Central and Eastern Europe due to geographical affinity as well as the fact that the reform of their pension systems has taken place recently. In our opinion, the experience of pension reform in Poland is most useful, as Ukraine has chosen its pension system, since Poland and Ukraine belong to countries with "old" people and large-scale state pension insurance programs.

The experience of the United Kingdom and the United States is developmental, as they could reconcile the solidarity pension system with private pension insurance, as well as the experience of Latin American countries, that in an economic environment similar to the Ukrainian ones, were able to create an effective network of non-state pension provision and become an example for other countries of the world for the development of private pension insurance systems. As far as agricultural workers in these countries are concerned, they are members of the pension system on a general basis (Plakhtii, 2019).

Foreign experience convinces that most countries use a mixed pension system in which redistributable pension models are generally compulsory, while cumulative ones are used in voluntary and obligatory forms. Studies show that the prevailing is the redistributive pension system, which accounts for an average of $68 \%$ of all retirement benefits in most developed countries, while compulsory cumulative pension systems account for $19 \%$ and voluntary cumulative pension schemes is $13 \%$.

\section{Conclusions}

Thus, summing up the research conducted on the functioning of pension systems in different countries of the world and the main directions of their reform, it would be reasonable to conclude that reforming the national pension system is an extremely complex task in the socio-economic aspect, since there is no single universal model that would satisfy any. The choice of a pension system depends, first of all, on the demographic situation of the country, the level of its economic development (Nicoholas, 2002).

In the countries of the world different approaches to the solution of pensions of the rural population are chosen. In Western Europe certain programs have been developed for those employed in agricultural production. In Germany and France individual pension schemes have been created for agricultural commodity producers and in the United Kingdom and the United States they are part of the national pension system. However, in most countries the state provides financial assistance to the rural population under retirement insurance.

Therefore, in order to succeed in providing pensions to the population of the state, Ukraine needs to improve its own pension system as soon as possible using the experience of foreign countries. 


\section{References:}

Aleskerova, Yu. V. (2009). Kredituvannya regional'nogo APK [Lending to regional agribusiness]. Zbirnyk naukovih prac, vol. 17, no. 2, pp. 645-648. Kamianets-Podilskyi.

Aleskerova, Yu., Mulyk, T., \& Fedoryshyna, L. (2018). Improving credit protection analysis methods Reports of main agricultural enterprises. Baltic Journal of Economic Studies, vol. 4, no. 2, pp. 1-7. doi: 10.30525/22560742/2018-4-2-1-7

Aleskerova, Yu., \& Fedoryshyna, L. (2018). Analysis of investment activities of enterprises of Ukraine. Economic system development trends: the experience of countries of Eastern Europe and prospects of Ukraine.

Aleskerova, Yu. V. (2008). Analiz stanu ta efektivnosti kreditnogo zabezpechennya vidtvorennya osnovnikh zasobiv sil's'kogospodars'kikh pidpriemstv [Analysis of the status and effectiveness of credit support for reproduction of fixed assets of agricultural enterprises]. Oblik i finansi APK, vol. 3, pp. 125-129.

Aleskerova, Yu., Fedoryshyna, L., \& Koval, N. (2018). Features of loan security for the reproduction of fixed assets for agricultural purposes. Baltic Journal of Economic Studies, vol. 4, no. 4, pp. 1-5. doi: 10.30525/2256-0742/20184-4-1-5

Rogach, S., Vdovenko, L., \& Polishchuk, O. (2019). Agriculture of Ukraine under the joint policy of the European Union. Baltic Journal of Economic Studies, vol. 5, no. 3, pp. 178-183. doi: 10.30525/2256-0742/2019-5-3-178-183

Plakhtii, T., Fedoryshyna, L., \& Tomchuk, O. (2019). Socio-economic component of preferential taxation of individuals' incomes. Baltic Journal of Economic Studies, vol. 5, no. 2, pp. 171-175. doi: 10.30525/2256-0742/20195-2-171-175

Myronenko, M., Polova, O., Prylutskyi, A., \& Smoglo, O. (2017). Financial and economic aspects of bioenergy development in the context of providing energy independence of Ukraine. Problems and Perspectives in Management, no. 15(4), pp. 243-253.

Myronenko, M., Polova, O., Khaietska, O., \& Koval, N. (2018). Capitalization of banks: theory, practice and directions of ensuring. Banks and Bank Systems, no. 13(1), pp. 173-183. doi: 10.21511/bbs.13(1).2018.16

Polova, O., \& Ruda, O. (2019). Modern Technologies in Economy and Management. Collective Scientific Monograph: The Academy of Administration in Opole.

Polova, O. (2018). Evaluation of investment attractiveness of the region. Conference Proceedings of the 7th International Scientific Conference Problems and Prospects of Territories' Socio-Economic Development (April 4-7, 2018, Opole, Poland). The Academy of Management and Administration in Opole.

Polyova, O. L. (2017). Management financial resources of agricultural enterprises. Sciences of Europe. Praha. Vol. 3. no. 11(11), pp. 58-63

Gusonka, D., \& Polova, O. (2018). Strategic directions of development of the agricultural market of Ukraine in nowadays international trade conditions. International Journal of Engineering Technologies and Management Research. India. Vol. 5(9), pp. 14-22. doi: 10.5281/zenodo.1435155

Todosiichuk, V. L. (2018). Kontseptualni zasady upravlinnia finansovymy resursamy derzhavnoho pidpryiemstva [Conceptual principles of financial resources management of a state-owned enterprise]. Infrastruktura rynku, Vol. 26, pp. 56-64.

Kritzer, B. E. (1996). Privatizing social security: the Chilean experience. Social Security Bulletin. No. 3, pp. 45-55. Kubicek (2005). Contribution rates to funded pension systems in the new member countries. Research in International Business and Financevol. No. 19, issue 2, pp. 266-280.

Leon, J. H. (2005). Population ageing and pension reform in a small open economy with non-traded goods. Journal of Economic Dynamics Control, no. 6, pp. 265-290.

Nicoholas George (2002). Sweden's savers are kept pasted on state of their funds. Financial Times. March 25.

Oskar Cerrangolo (2003). Pension Reform in Latin AmericConference on «Privatisation of Public Pension Systems - Forces, Experience, Prospects». Vienna. June 19-21.

Robert Holsmann (2003). Pension Reform in Europe: Process and Progress (paperback). June. 